\title{
Prevalence Of African Giant Snails For Parasites In A South-East Region Of Côte d'Ivoire
}

\author{
Karamoko Mamadou \\ Amani N'dri Saint-Clair
}

Laboratoire de Biologie et Cytologie Animales, UFR des Sciences de la

Nature, Université Nangui Abrogoua, Abidjan, Côte d’Ivoire.

\section{Touré Alassane \\ Komoin Oka Clarisse}

Laboratoire Centrale Vétérinaire de Bingerville, Service de parasitologie

(Laboratoire National d'Appui au Développement Agricole)

Bingerville, Côte d'Ivoire

Otchoumou Atcho

Fantodji Agathe

Laboratoire de Biologie et Cytologie Animales, UFR des Sciences de la

Nature, Université Nangui Abrogoua, Abidjan, Côte d’Ivoire

\section{Kouassi Kouassi Philippe}

Laboratoire de Zoologie-Biologie Animale, UFR Biosciences, Université

Félix Houphouët Boigny de Cocody, Abidjan, Côte d'Ivoire

doi: 10.19044/esj.2016.v12n21p186 URL:http://dx.doi.org/10.19044/esj.2016.v12n21p186

\begin{abstract}
Two species of snails (Achatina achatina and Archachatina ventricosa), from surrounding forest of Azaguiés district, were collected at the market of the locality aforementioned in order to identify their various parasites. For that, 50 snails of each species were sacrificed. Parasites were searched on the level of the flesh, between the flesh and the shell, the stomach, the intestine, the liver and the reproductive apparatus. The collected parasites were Balantidium spp, the larvae of Protostrongylus spp, the larvae of Dicrocoelium spp and Trichomonas spp. Our results showed that 52\% of Achatina achatina and $74 \%$ of Archachatina ventricosa were parasitized. Among the parasites collected in the snail Achatina achatina, 95.8\% were nematodes and $4.1 \%$ were trematodes. Whereas in the snail Archachatina ventricosa, $97.7 \%$ were protozoa, $8.8 \%$ nematodes and $0.4 \%$ consisting with trematodes. The prevalence of Protostrongylus spp (48\%) were higher than that of Dicrocoelium spp (4\%) in Achatina achatina. For the snail Archachatina ventricosa, the prevalence of parasite were dominated by
\end{abstract}


Trichomonas spp (38\%) and Protostrongylus spp (24\%).

Keywords: African giant snail, parasites, prevalence

\section{Introduction}

Some terrestrial molluscs of the genus Achatina and Archachatina are sources of proteins that are appreciated by population in Africa. The consumed snails come from essentially collecting carried out in the forests during the rainy seasons (Otchoumou et al., 1990). Therefore, it's not surprising that the preferential relative humidity of snail is between 75 and $95 \%$ and its optimal growth is $25{ }^{\circ} \mathrm{C}$ (Takeda and Ozaki, 1986). The annual consumption of this animal in Côte d'Ivoire reached 7800 tons in 1990. The consumption in Abidjan was around 1800 tons in 2008 (Kouassi et al., 2008).

However, many terrestrial mollusc species are regarded as intermediate hosts of trematodes (Manga-gonzalez et al., 2010). In addition the trematodes of Dicrocoelium genus would have as intermediaries' hosts Helix aspersa found in Turkey (Gurellï and Göçmen, 2007). Then, Shan et al. (2009) and Hu et al. (2011), announced a serious illness and sometimes fatal in mankind such as eosinophilic méningo-encephalopathy and the radiculomyélo-encéphalite whose Achatina fulica would be the vector. This snail is intermediate host of the nematode Angiostrongylus cantonensis. These studies related to only the species Helix aspersa and Achatina fulica. Achatina achatina and Archachatina venticosa not having been studied. However these two species are much consumed in Côte d'Ivoire (kouassi et al., 2008; Sika, 2015). So, would the species Achatina achatina and Archachatina venticosa are a potential reservoir of diseases? In other term do these two snails species are the reservoir of parasites?

In order to answer this question, we proposed this study which aims to identify parasites on two species of giant snail (Achatina achatina and Archachatina ventricosa) in the area of Azaguié.

\section{Material}

The biological material is composed of two snail species: Achatina achatina, Archachatina ventricosa.

The observation of the parasites was done with a binocular magnifying glass of mark CETI and a microscope of mark Carl Zeiss.

\section{Methods \\ Study area}

Snails used in this survey were collected in Azaguié, a locality of the forest belt of Côte d'Ivoire. Located at the South-east of the Côte d'Ivoire 
between the latitudes $5^{\circ} 35^{\prime}$ and $6^{\circ} 15^{\prime} \mathrm{N}$ and longitudes $3^{\circ} 55^{\prime}$ and $4^{\circ} 40 \mathrm{~W}$ (Figure 1), Azaguié is $40 \mathrm{~km}$ away from the north of Abidjan.

The choice of Azaguié is justified by the fact that this locality shelters a classified forest and several former studies showed that this area is snails' purveyor for the town of Abidjan.

\section{Sampling}

We did two missions to purchase snails. The first mission has been hold in 5 November 2011 and consisted in collecting randomly 50 snails of the species Archachatina ventricosa. The second mission took place in 4 December 2011 and it permitted us to collect also randomly 50 snails of the species Achatina achatina. The living and active snails of which shell was not damaged and without lesion on the flesh were taken. The dead snails or snails of which the shell was damaged, were not retained in this study.

The choice of 50 snails was made on the basis of formula suggested by Fosgate (2009):

$\mathrm{n}=\log \alpha /[\log (1-p)]$

$\mathrm{n}=$ required sample size

$\mathrm{p}$ = prevalence expected (found in previous study, failing of previous study a prevalence of $50 \%$ was fixed)

$\alpha=1$ - desired absolute precision (95\%)

The collection was made early in the morning in order to avoid contaminations from surrounding traders. The tow species of snail are packaged separately in the bags before display on the market stand. We bought snails when there were packaged in bags before traders exposed them on the market table.

\section{Transport}

The snails were conditioned in individualized sterile sachets and conveyed to the laboratory in a cooler bag.

\section{Macroscopic examination}

Once at the laboratory, the shell and the flesh of snails were thoroughly examined in order to prevent the animals having from lesions and damage on their shell.

\section{Preparation of the sample for parasitic analysis}

Collection of the external parasites was done by scraping the pedal plate by using a sterile blade of lancet in a sterile plastic box of Petri containing $40 \mathrm{ml}$ sterile distilled water. The shell of snails were broken with a stone cleaned beforehand (with liquid soap, rinsed with the 
A

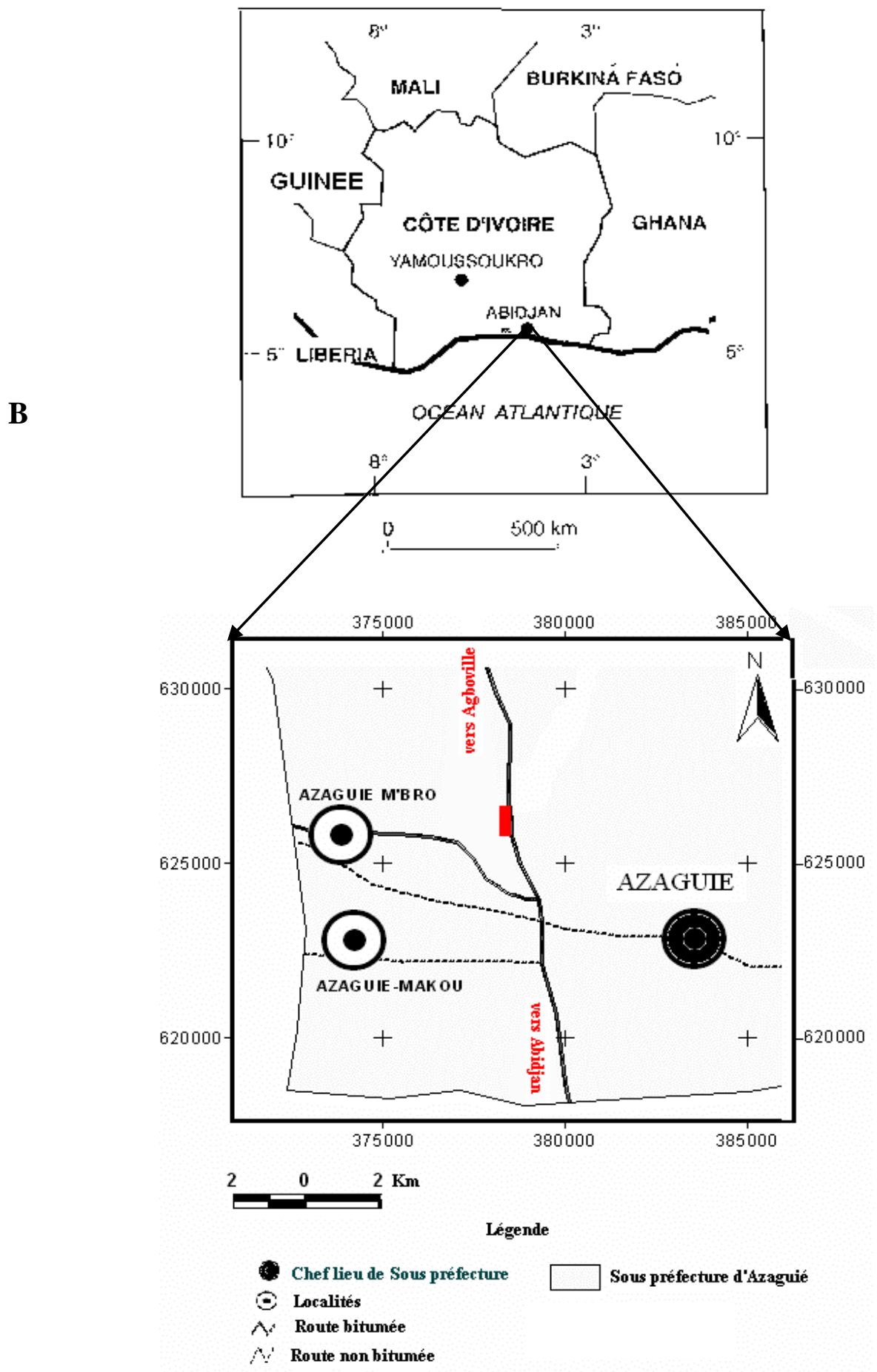

nFigure 1. Localization of the zone of study in the Southeast of the Côte d'Ivoire:

A: Map of Côte d'Ivoire, B: Situation of Sub-prefecture of Azaguié (Vroh et al., 2010). 
tap water followed by an ethanol bath at $70^{\circ}$ during 10 minutes). This operation has been implemented for each snail.

The parasites located between the flesh and the shell were collected by rinsing the visceral mass and inside the shell with $40 \mathrm{ml}$ sterile water distilled in a sterile plastic box of Petri.

After this operation, dissection was carried out with a sterilized pair of scissors and sterile pliers of dissection. The stomach, the intestine, the liver and the reproductive apparatus were taken. The organs were put individually in sterile plastic boxes of Petri.

The liver was incised with a sterile blade of lancet. This blade of lancet has been used to take a small quantity of the hepatic liquid. It has been laid on a blade slide. A sterile distilled water drop was added on. The solution was homogenized with the edge of a plate which has been used as cover. This operation was repeated three times at tow extremity and at middle of the same liver.

The other organs were split with a sterilized pair of scissors and the inside is scrapped with a sterile blade of lancets. The contents of stomach and reproductive apparatus were rinsed with $20 \mathrm{ml}$ and $30 \mathrm{ml}$ of sterile distilled water respectively. For the search of parasite eggs, 3g of feces contained in the intestine were collected. We used flotation and sedimentation methods.

\section{Parasites counting}

For the search and the quantification of parasite eggs, Mac Master technique were used with saturated solution of chlorure of sodium (density 1.20). In an aim to facilitate the counting of parasites, $5 \mathrm{ml}$ of each solution are taken and observed gradually until exhaust the total volume of each solution. The parasites observed in each time were identified and their manpower noted.

\section{Microscopic examination}

All solutions were watched with the binocular magnifying glass. The blades that stand the preparations have been observed in the microscope with magnitude of 100 and 400 .

\section{Identification of the parasites}

The identification of the parasites has been facilitated by the keys proposed by Thiempon et al., (1979), Troncy et al., (1981) et Basson, (2010).

\section{Prevalence}

The prevalence of snails for parasites according to their class and 
genus, were calculated with the following formula:

$$
P=(n i / N) * 100
$$

Where P : Prevalence of snails for parasite (\%)

ni : Number of snails infested

$\mathrm{N}$ : Total number of snails analysed

\section{Results}

\section{Distribution of the parasites according to the snail's organs}

The parasites collected in the two snail's species were Balantidium spp., the larvae of Protostrongylus spp., the larvae of Dicrocoelium spp., and Trichomonas spp.

No egg were found in feces. Table 1 shows parasites' distribution in the organs. While the other organs were not infected in Achatina achatina, three larvae of Dicrocoelium spp were found in the liver. Protostrongylus spp were present on the flesh (30 larvae), between the flesh and the shell (29 larvae), in the stomach (8 larvae) and in the intestine (3 larvae). The greatest values have been recorded on the flesh (30 larvae) and between the flesh and shell (29 larvae). The collected parasites in the snail Archachatina ventricosa were Balantidium spp., Protostrongylus spp., Dicrocoelium spp. and Trichomonas spp. Balantidium spp. were present on the flesh (9 parasites) and to a smaller extent in the reproductive apparatus (2 parasites). Protostrongylus spp. were collected in great number between the flesh and the shell (25 larvae) and on the flesh (14 larvae). Dicrocoelium spp. were only collected in the liver (2 larvae). Trichomonas spp., except in the liver, has been observed in all the organs: 245 on the flesh, 171 between the flesh and the shell, 7 in the reproductive apparatus; 3 in the intestine, and 2 in the stomach.

\section{Infested and no-infested snails rates}

Our works showed that $52 \%$ of Achatina achatina and $74 \%$ of Archachatina ventricosa are parasitized (Table 2).

\section{Prevalence level of snail for parasites' class}

Among the parasites collected on the snail Achatina achatina, 95.8\% were infested by the nematodes and $4.1 \%$ by trematodes. However none protozoans parasites were found on the snail Achatina achatina. Whereas on the other species Archatina ventricosa, 97.7\% of them were infested by the protozoans, $8.8 \%$ by nematodes and $0.4 \%$ by trematodes (Table 3 ). 
Table 1: Distribution of the parasites according to the organs of the snails Achatina achatina and Archachatina ventricosa

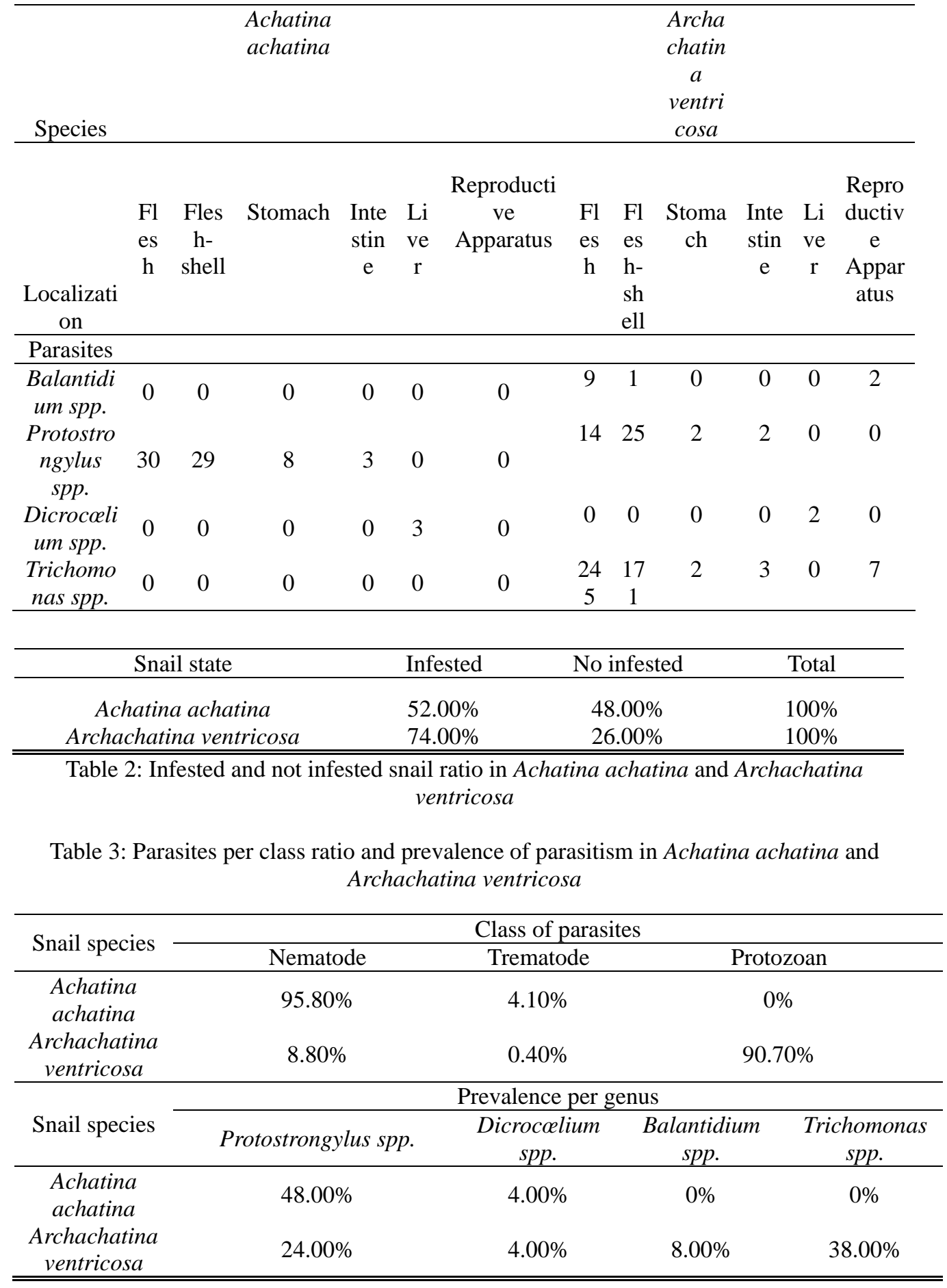




\section{Prevalence level of snail for parasites' genus}

The prevalence in Achatina achatina is $4 \%$ for Dicrocoelium spp, $48 \%$ for Protostrongylus spp. On the contrary, zero for Balantidium spp. and Trichomonas spp. (table 3). In Archachatina ventricosa, it's $38 \%$ for Trichomonas spp, $24 \%$ for Protostrongylus spp., $8 \%$ for Balantidium spp. and $4 \%$ for Dicrocoelium spp.

\section{Discussion}

The parasites collected in the two snail's species were Balantidium spp, the larvae of Protostrongylus spp., the larvae of Dicrocoelium spp, and Trichomonas spp. The presence of these parasite could be justified by the fact that these species of snails would present a favourable environment to their development. The harvest of Protostrongylus spp. and Dicrocoelium spp. larvae corroborates the results of Dreyfuss and Rondelaud (2011) who observed that the terrestrial molluscs constitute intermediate hosts for most of nematode and trematode species.

The distribution of the parasites according to the organs revealed that Archachatina ventricosa was more parasitized than Achatina achatina as well in a number of parasites as in species. This species would displays more favorable for the survival of parasites. The larvae of Protostrongylus spp were very frequent on the flesh and between the shell and the flesh. Protostrongylus spp contaminates snail in its larval form (L1) by penetrating in the flesh of mollusk then leave it at the L3 stage (Dreyfuss and Rondelaud, 2011). Dicrocoelium spp was only localized in the liver. This finding seems to confirm the fact that it is a parasite of liver (Ducommun and Pfister, 1991; Gurellï and Göçmen, 2007).

Achatina achatina was infested at 52\% and Archachatina ventricosa at 74\%. Indeed Dreyfuss and Rondelaud (2011) maintain that the majority of the species of parasites would have closely specificity for the mollusc hosts species. Our works showed that Archachatina ventricosa is infested at $97.7 \%$ by the protozoa, $8.8 \%$ by the nematodes and at $0.4 \%$ by the trematodes. This preponderance of protozoa would be due to the conditioning. Because a flora and a fauna are associated to snails. This flora and this fauna could become explosive when the environment allows it (Pirame, 2003).

The prevalence of Dicrocroelium spp. were $4 \%$ for Achatina achatina and also for Archachatina ventricosa. This prevalence were higher than the result obtained by Gurellï and Göçmen (2007) in Helix aspersa (0.97\%). However it were lower than the result obtained by Fashuyi-and Adeoye, (1986) in Limicolaria flammea (30\%), Limicolaria striatula (20\%) and Lamellaxis gracilis (20\%). Additionally, we noticed that Fashuyi and Adeoye (1986) observed nothing in 25 Achatinidae. This weak prevalence would be related to the mollusc species used in our work (Achatina achatina and 
Archachatina ventricosa).

The prevalence of Protostrongylus spp. were $24 \%$ and $48 \%$ respectively in Archachatina ventricosa and Achatina achatina. Our results were largely higher than those of Sher et al. (2006) obtained in goats (1.05\%). According to Dreyfuss and Rondelaud (2011) these parasites require the terrestrial mollusc intervention to ensure their transmission to the herbivorous. Moreover, the high-risk period includes November and December for molluscs (Cabaret et al., 1980). Our samplings have been carried out in November and December 2011.

The prevalence of Trichomonas spp (38\%) and Balantidium spp (8\%) in Archachatina ventricosa seem to be new for us. Since Balantidium is a parasite of monoxene characteristic. It means that its evolution proceeds on the same host or partially in the external environment. Pig, man, dog, wild monkey and rodents are final hosts (Nanfah, 2008). The snails would probably contaminate in their origin environment. Did these parasites contaminate Archachatina ventricosa? Is Archachatina ventricosa an intermediate host for these parasites? Lastly, are these parasites pathogenic for this mollusc? Many interrogations which deserve further studies.

\section{Conclusion}

At the end of this study, we can retain that Achatina achatina and Archachatina ventricosa were colonized by larvae of nematodes, Protostrongylus spp, and trematodes, Dicrocroelium spp. The species Archachatina ventricosa is also infested by protozoa such as Trichomonas spp and Balantidium spp. Archachatina ventricosa were more infested than Achatina achatina. Another strong idea would be a prospective survey over the year in order to analyze evolution and dynamic of infestation and infection rates.

\section{Acknowledgement}

We thank Consortium Wellcome ${ }^{\text {Trust }}$ which has financed this work in the context of Afrique One project: One Health Initiative - African Research Consortium for Ecosystem and Health Population. We also thank Parasitology Laboratory, a unit of Laboratoire Central Vétérinaire de Bingerville (also part of Laboratoire National d'Appui au Développement Agricole) and Institut Pasteur of Côte d'Ivoire.

\section{Statement of conflicting interest}

The authors attest that there is no conflict of interest with regard to the authorship and publication of this manuscript. 


\section{References:}

Basson L. First records of trchodinid ectoparasite (Ciliophora: Peritrichia) from introduced freshwater fishes in Tasmania, Australia, with comments on pathogenicity. Acta Protozool. 49: 253-265. 2010.

Cabaret J., Dakkak A. and Bahaida B. Etude de l'infestation des mollusques terrestres de la région de Rabat (Maroc) par les larves de protostrongylidés dans les conditions naturelles. Revue d'Elevage et de Médecine Vétérinaire. Pays Trop. 33: 159-165. 1980.

Dreyfuss G. and Rondelaud D. Les mollusques dans la transmission des helminthiases humaines et vétérinaires. Bulletin Académique du Vétérinaire. France Tome 164 - №1. 2011.

Ducommun D. and Pfister K. Prevalence and distribution of Dicrocoelium denditricum and Faciola hepatica infection in cattle in Switzerland. Parasitological Research. 77: 364-366. 1991.

Fashuyi S. A. and Adeoye G. O. The possible snail intermediate hosts of dicrocoelium hospes in Nigeria. Acta Veterinaria Brno. 55: 85-88. 1986.

Fosgate G. T. Practical sample size calculations for surveillance and diagnostic investigation. Journal of Veterinary Diagnostic and Investigations. 21: 3-14. 2009.

Gürelli G. and Göçmen B. Natural Infection of Helix aspersa (Mollusca: Pulmonata) by Dicrocoeliidae (Digenea) Larval Stages in Izmir, Turkey. Türkiye Parazitoloji Derg. 31 (2): 150-153. 2007.

Hu X., Du J., Tong C., Wang S., Liu J., Li Y. and He C. Epidemic status of Angiostrongylus cantonensis in Hainan Island, China. Asian Parasitological Journal in Tropical Medicine. 4 (4):275-7. 2011.

Kouassi K. D., Otchoumou A. and Gnakri D. Le commerce des escargots (Achatina achatina), une activité lucrative en Côte d'Ivoire. Livestock Research for Rural Development. 20, 4. 2008.

Manga-gonzalez M. Y., Quiroz-romero H., Gonzalez-lanza C., Minambres B. and Ochoa P. Strategic control of Dicrocoelium dendriticum (Digenea) egg excretion by naturally infected sheep. Veterinary Medicine. 55, (1): 19-29. 2010.

Nanfah W. M. P. Etude du poly parasitisme intestinal à l'INRSP, dans le district de Bamako - Mali. Thèse de Doctorat en pharmacie. 137p. 2008.

Omole A. J., Saka J. O., Sansi J. A. A., Ogundolaf I., Oluokun J. A. and Adebowale E. A. Managemental praticies in snails farming in ibadan, Oyo State. Moor Journal of Agricultural Research. 1: 86-92. 2000.

Otchoumou A., Zongo D. and Dosso H. Contribution à l'étude de l'escargot géant africain: Achatina achatina (Linné). Annales d'Ecologie, Université Nationale de Côte d’Ivoire. 21: 31-58. 1989-1990.

Pirame S. S. L. Contribution à l'étude de la pathologie estivale de l'escargot Petit-gris (Helix aspersa): reproduction expérimentale. Thèse de doctorat 
vétérinaire, Ecole Nationale Vétérinaire de Toulouse. 97p. 2003.

Shan L., Yi Z., He-Xiang, Ling H., Kun Y., Peter S., Zhao C., Li-Ying W., Jürg U., and Xiao-Nong Z. Invasive Snails and an Emerging Infectious Disease: Results from the First National Survey on Angiostrongylus cantonensis in China. Plos Neglected Tropical Diseases. 3 (2): 23-68. 2009. Sher A., Muhammad N., Roomana G., Muhammad Z. and Abdul R. Natural infection of sheep and goats with Dictyocaulus filaria and Protostrongylus rufescens (nematoda) in Quetta, Pakistan. Pakistan Journal of Zoology. 38 (2): 173-175. 2006.

Sika N. A. Evaluation des stocks d'escargots comestibles en Côte d'Ivoire et essai de la production en élevage de deux espèces d'Achatinidae: Achatina fulica (Bowdich, 1720) et Archachatina marginata (Swainson, 1821) à partir d'aliments formulés à base de protéines. Thèse d'Etat ès sciences naturelles, Université Félix Houphouët Boigny. 167 p. 2015.

Takeda and Ozaki. Introduction of locomotor behavior in the giant African snail, Achatina fulica. Comparative Biochemistry and Physiology. 83 (A): 77-82. 1986.

Thienpon D., Rochette F. and Vanparijs O. F. J. Diagnostique de verminose par examen coprologique. 187 p. 1979.

Troncy M. P., Itard J. and Morel P. C. Précis de parasitologie vétérinaire tropicale. 117p. 1981.

Vroh B. T. A., Adou Y. C. Y. and Kouamé D. Diversités Floristique et Structurale sur le Site d'une Réserve Naturelle Volontaire à Azaguié, Sud-est de la Côte d'Ivoire. European Journal of Scientific Research. 45: (3) 411421. 2010. 